\title{
Sustainable Agriculture, Food Production and Poverty Lessening in Nigeria
}

\author{
Cordelia Onyinyechi Omodero
}

Department of Accounting, College of Management and Social Sciences, Covenant University Ota, Ogun State 110001, Nigeria

Corresponding Author Email: onyinyechi.omodero@ covenantuniversity.edu.ng

https://doi.org/10.18280/ijsdp.160108

Received: 23 April 2020

Accepted: 17 November 2020

\section{Keywords:}

agriculture, poverty, farm, agriculture finance, food security, JEL classification codes: O13, P46, Q12, Q14, Q18

\begin{abstract}
The challenge of persistent poverty and food insecurity in Nigeria has been an issue of concern. The government's effort to alleviate poverty in Nigeria through agriculture appears ineffective because most poor people are rural dwellers and are coincidentally the farmers. They seem not to be benefiting from the government interventions to support farming due to corruption and other unquantifiable factors. This study investigates the impact of agricultural output and food production on poverty decrease in Nigeria. The data used in this study span from 2009 to 2019. Relevant diagnostic tests and regression analysis are performed to obtain the empirical evidence highlighted in this paper. Thus, the findings reveal that the Food Production Index significantly and positively impacts poverty reduction, while Agricultural Output has an immaterial negative effect on poverty decrease. The study concludes that poverty alleviation in Nigeria and food security will depend on government's full involvement in agriculture and improvement on its agricultural budget. Accordingly, the provision of necessary facilities to boost agriculture have been recommended. The facilities include modern farming equipment, sufficient power supply, credit facility, storage facility, and large markets.
\end{abstract}

\section{INTRODUCTION}

Agriculture refers to the tilling of land for sustenance and commercial produces, fishing, forestry, hunting and all undertakings that transmit to taking out possessions of nature from the ground [1]. Growth in agriculture in Nigeria has adjudged the most vital economic strategy to eliminate poverty, guarantee food security, ensure the quality of life enrichment and providing the economy with a resourceful long-lasting boost. Kilima et al. [2] submit that agriculture's growth should be advantageous to the underprivileged agriculturalists. It could be through agrarian output enhancement and job availability. According to Kilima et al. [2], a nation stands to benefit so much from agriculture. Agriculture reduces food consumption cost, curtails the frequencies of people migrating from the rural areas to the urban regions. It also increases nonfarm economic growth, provides the local people with the opportunity to contribute to financial decision-making procedures, and makes available nutritional products for consumption.

Historically, the evolution of agriculture is targeted towards food supply, job creation and poverty elimination. By implication, it behoves nations to benefit from agriculture's various potentials to sustain lives and reduce poverty. Based on this background, any country that neglects its agricultural sector is vying for poverty and food insecurity. Agriculture does not have a substitute in food supply and also plays a significant role in poverty lessening. The neglect of agriculture in Nigeria is why the decline in the annual agricultural contribution to GDP. Thus, agrarian progress and GDP progression influence the disparity, insufficiency, and dietary situation of a nation's entire populace [2]. Consequently, the whole economy is being affected as there is no substantial boost from agriculture to the economy.

In Nigeria, land and water are the copious possessions the country possesses. Following this natural endowment, agriculture in Nigeria has all it takes to be successful. Nevertheless, the future growth of agriculture in Nigeria suffers some drawbacks, and its effect on poverty alleviation and food security is yet to attain the desired benchmark. This is due to shortage of finance and access to a low-interest loan for farmers, insufficient government participation, inadequate infrastructures, lack of modern agricultural equipment, lack of training for farmers, natural disasters, unstable power supply, poor storage amenities, absence of market institutions and low transport system [3-6].

Administrations in Nigeria have introduced numerous strategies to uncheck the possibilities of agriculture in ensuring regular food supply in the country and becoming a major exporter of food. These strategies include: Operation Feed the Nation (OFN), Green Revolution, National Food Acceleration Production Programme (NAFPP), Directorate of Food, Road and Rural Infrastructure (DFRRI), among others [5]. These identified platforms were unsuccessful due to policy contradictions and fraud [7]. President Obasanjo initiated a cassava scheme from 2004 to 2005 to promote agriculture. Late President Yar Adua' 7 point plan focused on adequate food supply. Simultaneously, the immediate past President, Goodluck Ebele Jonathan, introduced agricultural transformation scheme as an extension of the fight for food security in Nigeria [5]. Notwithstanding all these measures, agriculture has not met the required target of providing sufficient food to match the increasing population due to inadequate government expenditure in the sector. As a result, 
poverty alleviation through agriculture remains a mirage [8].

In other words, all attempts made by every successive administration and foreign donor agencies to lessen poverty in Nigeria proved abortive [9]. Over $70 \%$ of the people living in abject poverty in Nigeria reside in the rural areas where agriculture is still at a microscopic scale [10], followed by numerous limitations inhibiting it from addressing the issue of poverty and food security. Thus, most poor people comprising small scale farmers live from hand to mouth due to their inability to turn out farm produce in commercial quantities. Gassner et al. [11] argue that a policy formulation that depends on the household farming as the medium to achieve the transformational change objective is not likely to succeed because most household farming is too insignificant to provide adequate food for the hungry masses.

Besides, agriculture lacks the necessary incentives from the authorities in the country. As a result, the poor farmers struggle to make ends meet [11] with little or no motivation. This study aims to determine the efficacy of agriculture in poverty reduction by employing agricultural productivity level and food production index to test the effect of agriculture on the purchasing power of the public. The study has five stages: the introductory part, the literature review, materials and methods, data capturing technique, analysis and interpretation, and the conclusion and recommendation.

\section{LITERATURE REVIEW}

\subsection{Conceptual clarification}

\subsubsection{Poverty}

Annual Abstract of Statistics [12] defines poverty as the unavailability of revenue necessary to guarantee access to life requirements, comprising the right to health services, education, and other essential services. Poverty refers to a situation of scarcity, inadequacy or shortage of monetary possessions necessary to meet physiological and basic human necessities. These include nutritional food, wears and accommodation, safe drinking water and other essential health facilities; thereby, climaxing into dispossession, the constraint of selections, and pitiable living standards [13]. Nevertheless, starvation is an unswerving indicator of paucity, consisting of the dearth of nourishment, wear and housing, and nonexistence of right to use health facilities [14]. Poverty and starvation are both conditions of lack; the underlying difference between them is that, while poverty is a shortage of purchasing power to access basic needs, hunger is the absence of those elementary essentials; hence, there cannot be starvation without poverty [14].

\subsubsection{Purchasing power parity}

Purchasing power parity (PPP) is a standard measuring tool used for macroeconomic assessment when comparing fiscal output and people's living condition. Gross domestic product (GDP) by PPP, based on a basket of goods, maybe an unbiased comparison between countries because nominal GDP comparisons can be erroneous due to possible manipulations on currencies. Thus, PPP refers to a fiscal concept that compares diverse nations' currencies by employing a "basket of goods" technique. Based on this fact, some countries adjust their GDP statistics to reflect the PPP [15].

\subsubsection{Food production index and food insecurity}

Food production index comprises food crops which are considered fit for human consumption and are nutritive. Still, coffee and tea are inclusive because they have no nutritional worth despite being eatable [16]. Food insecurity is a scenario where the precise measure and nutritional value of food for a healthy living are lacking or insufficient $[3,17]$. Reutlinger [18] submits that food insecurity is where millions of households do not have access to sufficient nutritious food, which results in physical and mental impairment in children and adults not being able to function at full capacity. In a more definite statement, Gassner et al. [11] posit it that low farming households do not have the purchasing power to obtain safe enough, nutritious food all through the year. Following the African Agriculture Status report, food insecurity is blamed on the constraint of adopting more prolific and expanded farming techniques and machinery types [19].

\subsubsection{Food security}

Conversely, a nation is adjudged to be food safeguarded when a more significant percentage of the entire populace can continuously obtain a sufficient amount of nutritional food to promote a healthy living $[20,21]$. Thus, food security is where nourishing food is insufficient supply to all the people in a nation or locality to maintain a healthy living [22]. According to Ayodeji and Oladokun [14], food security can only be realized if edible food is available and accessible by most of a nation's population. Ojo and Adebayo [23] explain that food security does not necessarily mean food availability in terms of quantity and quality but should instead be assessed from the viewpoint of suitability for healthy consumption when it comes to safety and hygiene. This is a big task because food production, consumption cost and market underlying forces will determine food availability [22, 24]. The purchasing power to enable accessibility to the food will depend on people's income and financial plan restraints [14]. When available, how safe, hygienic and healthy is the food? Some foods could lead to mass destruction if they contain harmful components or absence of basic hygiene in the processing.

\subsubsection{Agriculture}

According to Omodero and Amah [6], "agriculture comprises all aspect of crop production, fisheries, forestry and livestock farming". The economic value of agriculture in an economy includes food provision for a nation's inhabitants, fibres for local manufacturers, foreign earnings and market for industrial raw materials [25]. Agriculture is key to attaining worldwide poverty-lowering goals as the only supreme vital prolific sector in most low-income nations. Thus, agriculture's capability to produce total GDP progression and its relative benefit in decreasing poverty differs from country to nation [26].

\subsection{Theoretical framework}

Scholars such as [5, 11, 27], among others, opine that agriculture has the potential to alleviate poverty and ensure food security at all times. This is not just an issue of lowincome nations on focus, but a global consideration to proffer a lasting solution to poverty and food insecurity worldwide. This reality becomes evident because some nations' poverty places so much burden on the rest of the world and reduces living standards, especially when helping hands are sought or given during the global economic crisis. Based on this 
consensus by scholars and researchers, the theory of agriculture as a tool for global poverty reduction is supported by this work. Someone may perceive Agriculture's potential to reduce poverty and supply food to be little, especially in lowincome nations' affairs. However, this view from the global context is erroneous [26, 28] as agriculture is universally required to solve food insecurity globally. Agriculture is the only effective instrument for poverty alleviation and food supply with some global influence level, whether the nations in question are industrialized or unindustrialized.

\subsection{Empirical review}

Ivanic and Martin [29] used a global general equilibrium model and a set of microeconomic household models for a sample of 26 developing countries to examine the possible impacts of higher agricultural productivity (through genetically modified plants) on household incomes, farmers' earnings and poverty lessening. The study found that higher agricultural productivity emanating from research and development significantly reduced poverty by lowering the cost of low household consumption. Another finding of the study is that improving agricultural productivity among developing countries could lead to poverty reduction in the global context. Dim and Ezenekwe [30] applied the NeweyWest method and ordinary least squares to model the life expectancy against agricultural productivity and expenditure. The study illuminated that agrarian productivity with a coefficient of 1.17 implied that agriculture output could enhance life expectancy (a proxy for economic development) by 1.17 per cent in Nigeria. However, the study emphasizes that agricultural productivity is inadequate to enhance countryside life, except it is complemented by an equivalent off-farm job establishment, enlargements in schooling, health, and other community facilities. The discovery put forward that critical step is expedient if agricultural productivity must be utilized to restraint the effect of poverty and hunger while ensuring food security in the country.

Kilima et al. [2] employed data from on-farm research projects in Tanzania to inquire whether the government interventions in agriculture benefit the farmers who could at least make some notable impacts on the economy. The study used questionnaires for the data collection on impact assessment while coefficients of variation, Gini coefficients and Theil's t-statistic were used for income distribution assessment. The result showed that agriculture interventions improved farm income by increasing agricultural output and enhancing sales of products. Dhrifi [31] employed 32 SubSaharan African (SSA) countries' annual panel data ranging from 1990 to 2011 to determine the relationship between agricultural productivity and poverty reduction. Using a simultaneous equation model, the study found that agriculture contributed significantly to economic growth and poverty lessening in SSA countries. Oyakhilomen and Zibah [27] used ARDL bound testing technique to examine the impact of agricultural productivity on poverty reduction in the rural area. The scope of the study covered a period from 1970 to 2011 . The result indicated that agrarian productivity was substantial in affecting economic growth favourably but could not reduce poverty due to less attention given to investment in the agricultural sector.

Ejiogu and Palaniappan [32] used an investigative technique of interview and observation to determine the effect of Rural Finance Institution Building Programme (RUFIN) project on small-scale farmers. The study established that RUFIN objective was to improve agriculture, reduce poverty and create jobs for poor rural dwellers. The study concentrated on four communities in Anambra State, including Anaku, Omasi, Umuonyiba and Enugu-Abo. The researchers interviewed ten small scale farmers from each district. From their responses, the study established that the agricultural development, poverty alleviation and job creation were made possible through access to a low-interest loan received by the farmers through RUFIN project intervention.

Kadir and Amalia [33] assessed the degree of agricultural sector contribution to enhancing the non-agricultural sector's performance in the rural areas and their combined effect on poverty reduction in rural areas. The study employed data from 2002 to 2018 and analyzed them by applying simultaneous equations and regression model. The study found evidence that agriculture enhanced non-agricultural sector by 1.35 per cent while sectors boosted poverty alleviation by 3.91 per cent. Thus, the study results indicated that the agricultural industry is the driving force of economic growth and an effective mechanism to reduce poverty in rural areas. Eseyin et al. [4] examined agricultural investment on poverty alleviation in Nigeria. The study employed secondary data covering a period from 1985 to 2012 and relevant econometric tools for analysis. The findings revealed that agriculture investment was more effective in reducing poverty to a more significant measure.

John and Dankawu [34] did a study that covered a period from 1981 to 2014 and used principal component analysis and vector error correction model to analyze agriculture's effect on poverty reduction in Nigeria. Through variance breakdown, the study discovered that shock on all agriculture components in Nigeria had a material influence on poverty reduction. In a different research, Ayodeji and Oladokun [14] employed the Johansen co-integration test and regression analysis to examine agricultural productivity's effects on poverty alleviation in Nigeria. The study covered a period from 2000 to 2016 and found evidence that government budget allocation and commercial banks credit to agriculture were not enough to boost agriculture to a level that it could reduce poverty in Nigeria. In contrast, the findings revealed that food production index and microfinance banks credit to agriculture impacted poverty and hunger reduction in Nigeria positively. Naminse and Zhuang [35] examined the relationship between farmer entrepreneurship and rural poverty alleviation in China by evaluating the extent to which farm entrepreneurship can aid poverty reduction in China. The study made use of 309 employees of farmer entrepreneurship in Guangxi Province using survey questionnaires. For the analysis of data, structural equation modelling and AMOS 21 were employed, and the findings revealed that the qualitative growth of farmers impacted significantly on rural poverty reduction.

Omodero and Amah [6] studied agriculture's role in reducing consumption expenditure in Nigeria from 1981 to 2017 using the ordinary least squares method. The study examined the contribution of each component of agriculture towards consumption cost reduction in Nigeria. The findings revealed that crop and livestock production impacted significantly and positively on consumption cost lowering. Simultaneously, the fishery had a material negative influence, but forestry was insignificantly harmful in affecting its consumption. However, there is a significant difference between this previous study and the present study. The latter focuses on the influence of agriculture in guaranteeing food 
security and poverty lessening. Osabohien et al. [1] investigated the possibility of agriculture to provide job opportunities for people to minimize poverty in the West African States which record about $40 \%$ of the low global population. The study employed the generalized method of moments (GMM) econometric technique and a panel data spanning from 2000 to 2016. The findings revealed that agriculture helped reduce poverty through earnings enhancement of the poor which became a function of their level of human capital development.

\subsection{Gap in literature}

Poverty reduction using agriculture has focused on both the previous and more recent studies examined in this work [1, 4, 31, 35], among others. Kilima et al. [2] stressed agriculture's ability to increase farm income, especially among rural dwellers, where poverty is peak. Dim and Ezenekwe [30] used life expectancy to assess agriculture's adequacy in enhancing life expectancy in Nigeria. Agricultural potential in reducing consumption cost was examined by $[6,29]$. Although all these studies that were reviewed dealt with poverty alleviation and economic growth enhancement using agricultural productivity, more studies are still required to highlight agriculture's potentials in both poverty reduction and food security assurance. However, this present study closes this gap by examining agricultural input in food supply and poverty reduction using recent records from 2009 to 2019 . Nigeria is a country that requires empirical findings that could drive policies in the direction of potential agricultural maximization for adequate food supply and other benefits. Thus, this study is intended to contribute to the literature review in this area of study.

\section{METHODOLOGY}

\subsection{Research design}

This study employs experimental and ex-post facto research design. The experimental design enables the researcher to collect relevant materials from various sources, for instance, course books, journal articles and publication in magazines and gazettes. The ex-post facto design allows the use of existing data and records and will not allow the researcher to manipulate the information to be collected.

\subsection{Sources of data collection}

The examination utilized a secondary form of data spreading over from 2009 to 2019. The investigators collected all data used in this examination from the Central Bank of Nigeria Statistical Bulletin, FAO website and The World Bank. Due to the difference in the data values, we communicated all the logarithm structure figures for consistency. The study adopted abnormal data cleaning which include: Screening, investigative check and treatment of errors [36]. At the screening stage, we eliminated all excess data, outliers, insconsistent distribution and other inferences. We also used standard statistical package, excel sheet and descriptive tools to select the data from 2009-2019. We conducted various diagnostic tests to ensure the model's suitability, normality, and data set. The treatment phase includes elimination of wrong data and correction of errors to ensure the data are suitable for the study.

\subsection{Model specification}

The functional and econometric association between the dependent variable and the independent variables are seen in the equation below:

$$
\begin{gathered}
\text { PPP }=\mathrm{f}(\mathrm{FPI}, \mathrm{AGR}) \\
\mathrm{LOGPPP}=\beta_{0}+\beta_{1} \mathrm{LOGFPI}+\beta_{2} \mathrm{LOGAGR}+\mu
\end{gathered}
$$

where:

PPP $=$ Purchasing Power Parity;

$\mathrm{f}=$ Function of the independent variables (FPI\&AGR)

FPI = Food Production Index;

AGR = Agricultural output;

$\beta_{0}=$ Constant;

$\beta_{1}-\beta_{2}=$ Regression coefficients;

$\mu=$ Error term.

On the a priori, we expect; $\beta_{1}>0, \beta_{2}>0$.

\section{DATA ANALYSIS AND INTERPRETATION}

\subsection{Trend analysis}

The trend study in Figure 1 provides evidence that the data of all the variables employed are growing at the same pace showing the potential of agriculture to reduce poverty and ensure food security.
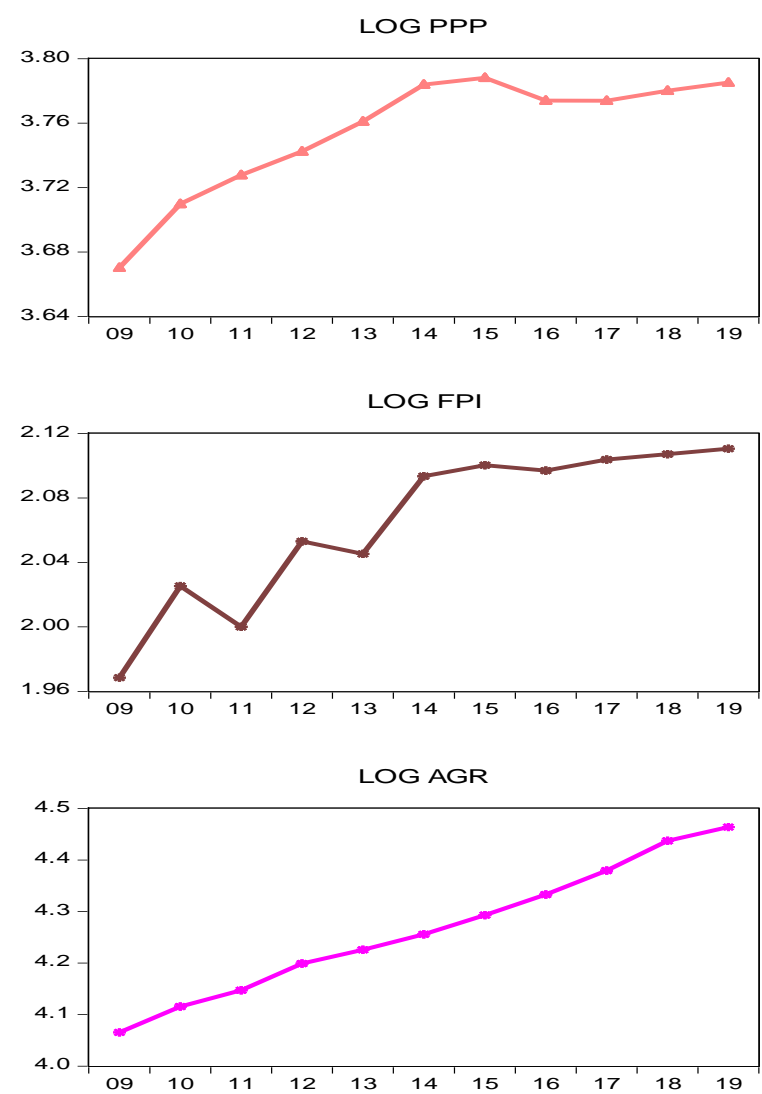

Figure 1. Source of data: CBN statistical bulletin, FAO website and world bank website 
The probability of the Ramsey RESET test in Table 1 is $0.33>0.05$.

Therefore, the distribution is stable, and it gives evidence that the model is free from a nonlinear relationship.

The result on Table 2 indicates absence of heteroskedasticity.

Table 1. Stability test

\begin{tabular}{cccc}
\hline \multicolumn{4}{c}{ Ramsey RESET Test } \\
\hline \multicolumn{4}{c}{ Equation: UNTITLED } \\
\hline Value & Df & Probability \\
t-statistic & 1.045820 & 7 & 0.3304 \\
F-statistic & 1.093740 & $(1,7)$ & 0.3304 \\
\hline Source: Authors' computation, 2020
\end{tabular}

Table 2. Heteroskedasticity test

\begin{tabular}{cccc}
\hline \multicolumn{4}{c}{ Heteroskedasticity Test: } \\
\hline F-statistic & 4.112238 & Prob. F (2,8) & 0.0591 \\
Obs*R-squared & 5.576096 & Prob. Chi-Square (2) & 0.0615 \\
\hline Source: Author's computation, 2020
\end{tabular}

\subsection{Normality test}

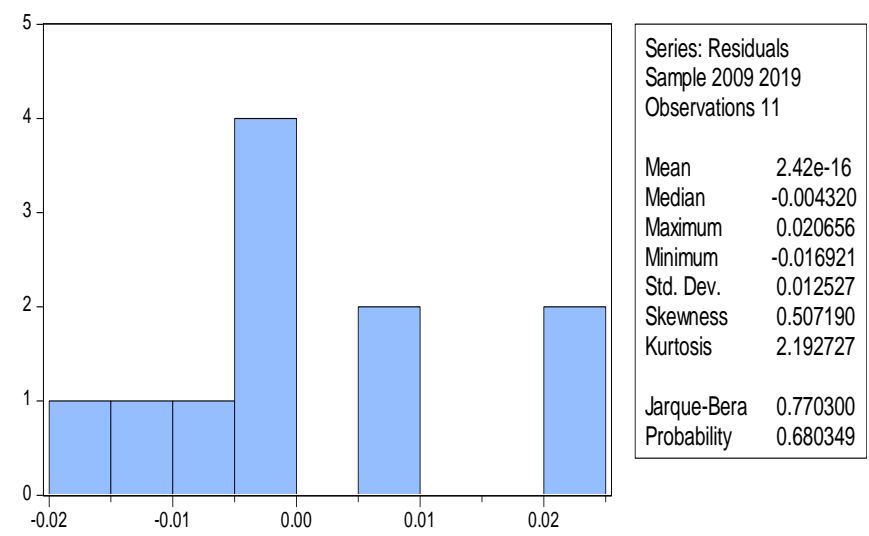

Figure 2. Histogram normality

Jarque-Bera probability of 0.7 in Figure 2 is greater than the significance level of 0.05 . Thus the data sets are typically distributed.

Table 3. Serial correlation test

\begin{tabular}{cccc}
\hline \multicolumn{4}{c}{ Breusch-Godfrey Serial Correlation LM Test: } \\
\hline F-statistic & 0.096599 & Prob. F $(2,6)$ & 0.9093 \\
Obs*R-squared & 0.343148 & Prob. Chi-Square (2) & 0.8423 \\
\hline Source: Author's computation, 2020 &
\end{tabular}

The probability of the Breusch-Godfrey Serial correlation test in Table 3 is $0.91>0.05$ materiality level. The assumption is that, if the p-value is below $5 \%$, there is serial correlation in the model.

Thus, the result suggests the absence of serial correlation in the model since 0.91 is above 0.05 .

The Variance Inflation Factor in Table 4 is $5.7<10$ benchmarks [37]. Thus, there is no multicollinearity between the explanatory variables used in this study.

Table 5 shows the regression result of this research. The result indicates that the correlation $(\mathrm{R})$ value is $94.4 \%$ which implies a stable relationship among poverty alleviation, food security and agricultural output. The coefficient of determination (R-squared) which is $89.1 \%$, is also very high. In other words, it is only $10.9 \%$ of the factors affecting poverty alleviation and food supply that are not captured in the model. All the same, the Durbin-Watson, which is approximately 2, indicates the absence of auto-correlation. The F-statistic has the value of 32.58280 with the p-value of $0.000<0.05$ materiality level. This result shows that the model is statistically significant, and the variables jointly affect poverty alleviation.

Table 4. Multicollinearity test

\begin{tabular}{|c|c|c|c|}
\hline \multicolumn{4}{|c|}{ Variance Inflation Factors } \\
\hline \multicolumn{4}{|c|}{ Date: $02 / 13 / 20$ Time: $23: 57$} \\
\hline \multicolumn{4}{|c|}{ Sample: 20092019} \\
\hline \multicolumn{4}{|c|}{ Included observations: 11} \\
\hline & Coefficient & Uncentered & Centered \\
\hline Variable & Variance & VIF & VIF \\
\hline LOG_FPI & 0.046657 & 11151.53 & 5.726744 \\
\hline LOG_AGR & 0.006618 & 6756.082 & 5.726744 \\
\hline$\overline{\mathrm{C}}$ & 0.038101 & 2136.435 & NA \\
\hline
\end{tabular}

Table 5. Regression result

\begin{tabular}{|c|c|c|c|c|}
\hline \multicolumn{5}{|c|}{ Dependent Variable: LOG_PPP } \\
\hline \multicolumn{5}{|c|}{ Method: Least Squares } \\
\hline \multicolumn{5}{|c|}{ Date: $02 / 14 / 20$ Time: 00:02 } \\
\hline \multicolumn{5}{|c|}{ Sample: 20092019} \\
\hline \multicolumn{5}{|c|}{ Included observations: 11} \\
\hline Variable & Coefficient & $\begin{array}{l}\text { Std. } \\
\text { Error }\end{array}$ & t-Statistic & Prob. \\
\hline LOG_FPI & 0.760259 & 0.216002 & 3.519685 & 0.0078 \\
\hline LOG_AGR & -0.013168 & 0.081351 & 0.161871 & 0.8754 \\
\hline $\mathrm{C}$ & 2.241177 & 0.195194 & 11.48180 & 0.0000 \\
\hline R-squared & 0.890659 & \multicolumn{2}{|c|}{ Mean dependent var } & 3.754224 \\
\hline $\begin{array}{l}\text { Adjusted R- } \\
\text { squared }\end{array}$ & 0.863324 & \multicolumn{2}{|c|}{ S.D. dependent var } & 0.037885 \\
\hline $\begin{array}{l}\text { S.E. of } \\
\text { regression }\end{array}$ & 0.014006 & \multicolumn{2}{|c|}{ Akaike info criterion } & $\begin{array}{c}- \\
5.471644\end{array}$ \\
\hline $\begin{array}{l}\text { Sum squared } \\
\text { resid }\end{array}$ & 0.001569 & \multicolumn{2}{|c|}{ Schwarz criterion } & $\begin{array}{c}- \\
5.363127\end{array}$ \\
\hline $\begin{array}{c}\log \\
\text { likelihood }\end{array}$ & 33.09404 & \multicolumn{2}{|c|}{ Hannan-Quinn criter. } & $\begin{array}{c}- \\
5.540048\end{array}$ \\
\hline F-statistic & 32.58280 & \multirow{2}{*}{\multicolumn{2}{|c|}{ Durbin-Watson stat }} & 1.917556 \\
\hline $\begin{array}{l}\text { Prob (F- } \\
\text { statistic) }\end{array}$ & 0.000143 & & & \\
\hline
\end{tabular}

Source: Author's computation, 2020

The t-statistics are used to explain the impact of the individual variables on poverty alleviation. The Food Production Index (FPI) has a t-statistic value of 3.519685 with the p-value of $0.00<0.05$. This result implies that FPI has a significant influence on poverty alleviation. FPI represents food crops which are considered healthy foods, excluding caffeine which is destructive to the body. Thus, this result agrees with the findings of $[6,27]$ in their study using agricultural productivity components. The two studies showed that crop production is significantly relevant in reducing poverty and consumption cost, respectively. The Agricultural Output (AGR) has the t-statistic value of -0.161871 and the pvalue of $0.87>0.05$. This result indicates that AGR is insignificantly negative in affecting poverty reduction in Nigeria. AGR comprises all components of agriculture and their combined effect on poverty reduction. 


\section{CONCLUSION AND RECOMMENDATION}

\subsection{Conclusion}

This study examines the impact of agriculture and the current food supply level on poverty decrease in Nigeria. From the regression result in Table 5, the Food Production Index (FPI) result provides evidence that the current status of food production in Nigeria is, to a greater extent reducing poverty. The implication is that if agriculture is well promoted, there will be food security in the country. The promotion of agriculture will minimize the issue of malnutrition and extreme level of poverty. AGR is the annual contribution of agriculture as a whole to GDP at current basic prices. That means all the components of agriculture put together at the moment cannot alleviate poverty in Nigeria. Poverty has persisted in Nigeria because farmers are neglected and treated with absolute disdain. Upcoming farmers and agriculturist are discouraged from pursuing the career due to lack of support from the authorities. Yet, entrepreneurship is being emphasized in the country due to lack of white-collar jobs for graduates. Even low-interest loans are not easy for farmers to access to expand their farming.

\subsection{Recommendation}

The recommendation that emanates from this study based on the empirical findings and the literature reviews is that the government should endeavour to provide the necessary facilities to boost agriculture in Nigeria. This study's required facilities include adequate power supply, storage facility, credit facility, fertilizer, seedlings, farmers' training, modern technology and farming equipment, extensive markets, right roads, and transport system. Human capital development in the country includes education of the workforce that can boost national growth [38] through tangible input in agricultural development. Some of the farmers lack the required training on how to handle pests destroying farm crops. Therefore, the government should endeavour to provide the necessary education for the farmers to boost agriculture in Nigeria. Government participation and budget increase for agriculture are also essential. Suppose the government can give farmers the necessary cooperation. In that case, it will go a long way to boost the output of all agriculture components in Nigeria and minimize poverty in the country.

\section{REFERENCES}

[1] Osabohien, R., Matthew, O., Gershon, O., Ogunbiyi, T., Nwosu, E. (2019). Agriculture development, employment generation and poverty reduction in West Africa. The Open Agriculture Journal, 13: 82-89. https://doi.org/10.2174/1874331501913010082

[2] Kilima, F.T.M., Tarimo, A.J.P., Johnsen, F.H., NchimbiMsolla, S., Mbaga, S., Sesabo, J., Iranga, G. (2013). The impact of agricultural research on poverty and income distribution: A case study of selected on-farm research projects at Sokoine University of Agriculture, Morogoro, Tanzania. Tanzania Journal of Agricultural Sciences, 12(1): $1-9$.

[3] Otaha, I.J. (2013). Food insecurity in Nigeria. An International Multidisciplinary Journal Ethiopia, 7(4): 26-35.
[4] Eseyin, O., Toluyemi, S.T., Oni, O.O. (2016). Investment in agricultural sector: Implication for poverty reduction in Nigeria (1985-2012). American Journal of Business and Society, 1(3): 118-128.

[5] Nwankpa, N.N. (2017). Sustainable agricultural development in Nigeria: A way out of hunger and poverty. European Journal of Sustainable Development, 6(4):

175-184. https://doi.org/10.14207/ejsd.2017.v6n4p175

[6] Omodero, C.O., Amah, K.O. (2018). Role of agriculture in reducing consumption expenditure in Nigeria. Journal of Management and Sustainability, 8(4): 130-138. https://doi.org/10.5539/jms.v8n4p130

[7] Ifeanacho, M.K., Nte, N.D., Nwagwu, J. (2009). The state, politics of poverty and food insecurity in Nigeria. International Bulletin of Business Administration. EuroJournals, Inc. Online http://www.eurojournals.com//BBa.htm

[8] Omodero, C.O. (2019). Government sectoral expenditure and poverty alleviation in Nigeria. Research in World Economy, 10(1): 80-90. https://doi.org/10.5430/rwe.v10n1p80

[9] Onumadu, F.N., Inyang, N.U. (2015). Analysis of effect of integrated farmers' scheme project on beneficiaries' income in Akwa Ibom state Nigeria. International Journal of Scientific and Technology Research, 4(3): 2277-8616.

[10] Olatomide, W.O., Omowumi, A.O. (2014). Policy interventions and public expenditure reform for pro-poor agriculture development in Nigeria. African Journal of Agricultural Research, 9(4): 487-500.

[11] Gassner, A., Harris, D., Mausch, K., Terheggen, A., Lopes, C., Finlayson, R.F., Dobie, P. (2019). Poverty eradication and food security through agriculture in Africa: Rethinking objectives and entry points. Outlook on Agriculture, 48(4): 309-315. https://doi.org/10.1177/0030727019888513

[12] Annual Abstract of Statistics (2010). National Bureau of Statistics, 2010. Abuja, Nigeria.

[13] Korankye, A.A. (2014). Causes of poverty in Africa: A review of literature. American International Journal of Social Science, 3(7): 147-153.

[14] Ayodeji, E.A., Oladokun, B.S. (2018). Agricultural productivity and poverty reduction in Nigeria (20002016). International Journal of Innovative Research \& Development, $\quad 7(9)$ : 330-338. https://doi.org/10.24940/ijird/2018/v7/i9/SEP18080

[15] Hall, M. (2020). What is purchasing power parity (PPP)? Available at: https://www.investopedia.com/updates/purchasingpower-parity-ppp.

[16] FAO. (2019). Food Production Index (2004-2006=100). Food and Agriculture Organization, Electronic files and website. http://www.fao.org/waicent/faostat/agricult/indicese.htm.

[17] FAO. (2015). The driving action across. The 2030 agenda for Sustainable Development, Rome.

[18] Reutlinger, S. (1985). Food security and poverty in less developed countries. Finance and Development Journal, 22(1): 7-22.

[19] AGRA. (2016). Progress towards agricultural transformation. Africa Agriculture Status Report 2016 (Nairobi) 
[20] Reutlinger, S. (1985). Policy options for food security (English). Agricultural Research Unit Discussion paper; no. ARU 44. Washington, D.C.: The World Bank. http://documents.worldbank.org/curated/en/8289214681 71861691/Policy-options-for-food-security.

[21] Idachaba, F. (2004). Food security in Nigeria: Challenges under democratic dispensation. Paper Presented at ARMTI, Ilorin.

[22] World Bank World Food Programme (2009). Comprehensive Food Security and Vulnerability Analysis. Available at: https//documents.wfp.org/stellent/groups/public/docume nts/manual_guide_proced/wfp20 3208.

[23] Ojo, E.O., Adebayo, P.F. (2012). Food security in Nigeria: An overview. European Journal of Sustainable Development, 1(2): 199-222.

[24] Honfoga, B.G., Van, D.B. (2003). Food consumption patterns in Central West Africa and challenges to combating malnutrition. Food and Nutrition Bulletin, 24(2): 167-182.

[25] Nazish, A.R., Iqbal, A., Ramzan, M. (2013). Impact of agriculture, manufacturing and service industry on the GDP growth of Pakistan. Interdisciplinary Journal of Contemporary Research in Business, 5(4): 727-734.

[26] Food and Agriculture Organization (FAO). (2012). The State of Food Insecurity in the World. Economic growth is necessary but not sufficient to accelerate reduction of hunger and Malnutrition. FAO, Rome, Italy.

[27] Oyakhilomen, O., Zibah, R.G. (2014). Agricultural production and economic growth in Nigeria: Implication for rural poverty alleviation. Quarterly Journal of International Agriculture, 53(3): 207-223.

[28] Dfid, E. (2005). Growth and poverty reduction: The role of agriculture. Policy Paper. London, DFID.

[29] Ivanic, M., Martin, W. (2010). Poverty impacts of improved agricultural productivity: Opportunities for genetically modified crops. AgBioForum, 13(4): 308-
313.

[30] Dim, C., Ezenekwe, U. (2013). Does agriculture matter for economic development? Empirical evidence from Nigeria. Journal of Finance and Economics, 1(1): 61-77.

[31] Dhrifi, A. (2014). Agricultural productivity and poverty alleviation: What role for technological Innovation. Journal of Economic and Social Studies, 4(1): 139-158.

[32] Ejiogu, L.C., Palaniappan, G. (2016). Poverty reduction through agricultural improvement and Access to credit: A confirmation from the small-holder farmers in Anambra State, Nigeria. Journal of Sustainable Development in Africa, 18(3): 116-124.

[33] Kadir, K., Amalia, R.R. (2016). Economic growth and poverty reduction: The role of the Agricultural sector in rural Indonesia. A paper presented at the Seventh International Conference on Agricultural Statistics. ICAS VII 2016 Rome, 26-28 October.

[34] John, M.A., Dankawu, M.U. (2018). Effect of agriculture on poverty reduction in Nigeria: A Multifaceted approach using principal component analysis. IOSR Journal of Humanities and Social Science, 23(6): 35-43. https://doi.org/10.9790/0837-2306093543

[35] Naminse, E.Y., Zhuang, J. (2018). Does farmer entrepreneurship alleviate rural poverty in China? Evidence from Guangxi Province. PLoS ONE, 13(3): 118. https://doi.org/10.1371/journal.pone.0194912

[36] Van den Broeck, J., Cunningham, S.A., Eeckels, R., Herbst, K. (2005). Data cleaning: Detecting, diagnosing, and editing data abnormalities. PLoS Med, 2(10): e267. https://doi.org/10.1371/journal.pmed.0020267

[37] Gujarati, D.N., Porter, D.C. (2009). Basic Econometrics (5th Ed.). Boston: McGraw-Hill Irwin. ISBN 978-0-07337577-9

[38] Omodero, C.O. (2019). Government general spending and human development: A case study of Nigeria. Academic Journal of Interdisciplinary Studies, 8(1): 5159. https://doi.org/10.2478/ajis-2019-0005 